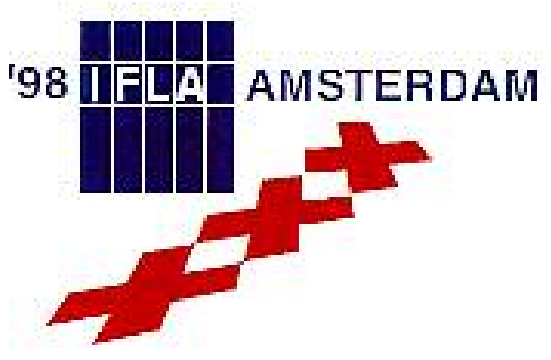

64th IFLA General Conference August 16 - August 21, 1998

Code Number : $129-140-E$

Division Number : VIII.

Professional Group : Regional Section: Asia and Oceania

Joint Meeting with : -

Meeting Number : 140.

Simultaneous Interpretation : No

Distance Education in Library and Information Science in Asia and the Pacific Region

Chutima Sacchanand 


\section{Distance Education in Library and Information Science in Asia and the Pacific Region}

Chutima Sacchanand

Abstract
This article identifies the distance education needs of information professionals
in the region and lists various institutions that offer distance education courses
in library and information science in Asia and the Pacific region along with
perspectives, media and methods, instructional systems, resources and services.
I
I

Distance education has gained popularity all over the world as a means of extending continuing education to all people, particularly professionals. It has been analyzed as a single product of the era of industrialization (Peters 1989: 3) and it has benefited from the rapid advances in electronic telecommunications in the 1980's and early 1990's. New communication technologies enable learning to take place beyond the classroom. Numbers of colleges, universities and institutions offer courses via the distance education system. As a result, someone pursuing a degree or trying to keep pace with new developments in their profession can often study the required courses without needing to enroll in a c o n v e n t i o n a l c a m p u s - b a s e d c o u r s e .

\section{The need for distance education for information professionals}

Information professionals have actually been involved in distance education since 1888, when Melvil Dewey called on the library school at Albany to develop correspondence courses for librarians in small and special libraries. Since then schools have permitted the enrollment of part-time students, scheduled evening and weekend classes, summer courses, and intensive sessions, and offered courses away from the home campus and other alternatives to a "traditional" classroom education (Barron 1991: 41). 
In this important development of the information age, emphasis is on the need for further education, continuing education and lifelong education for the information professionals and those who have already been in the workforce. Distance learning is the most useful and cost-effective means of enhancing or updating information and library skills and qualifications (Stoker 1995: 3). One of distance education's strengths is its ability to integrate diverse skills and professional backgrounds (Markowitz 1990: 49).

The growth of college and university level distance education in recent years has been striking with regard to both the number of students undertaking study at a distance and the numbers of institutions providing distance education in library and information science. The electronic age provides challenges for information professionals. As libraries and information centers focus on managing electronic records and virtual libraries, distance education provides various opportunities for information professionals:

1. It provides opportunities to acquire or update skills and knowledge in areas

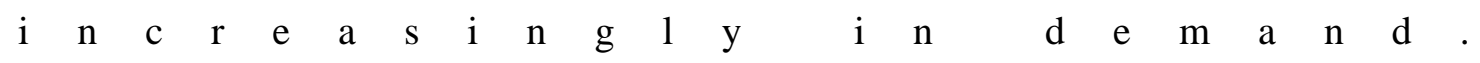

2. It enhances already acquired professional qualification. Individual subjects may be taken as continuing education courses, without the need to meet formal entry

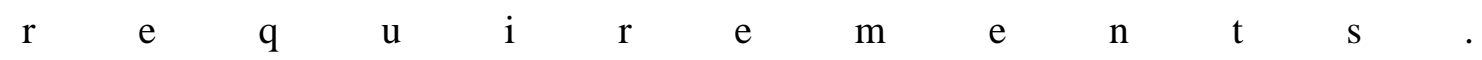

3. It increases access to education and meets the needs of learners who are

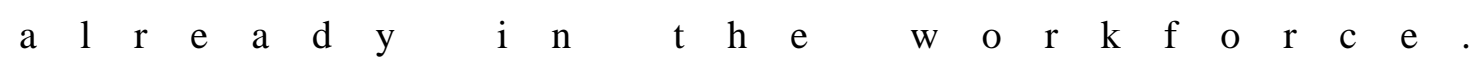

4. It emphasizes freedom from classroom limitations in location and time. Distance education is flexible with variable times and locations, whether at work or at home. Time to learn is expanded to fit individual needs.

5. It offers a chance to information professionals and people who live and work in remote areas and have no way of improving and continuing their education.

6. It creates opportunities for people with families and work commitments who are unable to further their studies at conventional universities.

\section{Distance education in library and information science: A survey}

In 1989, the British Library Research and Development Department published its British Library Research Paper 50 entitled "Distance Education in Library and Information 
Studies: a Survey" made by J A Haythornthwaite and F C P White (1989). One hundred and eighty-eight library schools and institutions in the English-speaking world were contacted, of which eighty-two responded, a rate of just over forty-three percent. It is shown that the range of courses offered through distance education is extremely wide from a thirteen-week course in "statistics for librarians," to full degree courses at all levels, including a doctorate. This survey has produced an annotated listing of relevant packages currently offered, or shortly to be offered. Some interesting and important points have emerged from the survey which are discussed, e.g., concern about the financial viability of distance education, anxiety about the isolation of distance learners and teachers. In certain areas of study, practical difficulties loom large; the use of sophisticated equipment requires "hands-on" experience which is very expensive to provide for distance-learners. In spite of these reservations, the interest demonstrated by many respondents indicates a wide-spread desire for knowledge of what can be achieved in this important and d e v e loping a r e a f e d u c a t i o n a l practice.

\section{Countries and institutions in Asia and the Pacific Region offering library andinformation sciencedistance education}

The National Institute of Multimedia Education (NIME), Japan, in collaboration with United Nations Educational, Scientific, and Cultural Organization (UNESCO) made "A Survey of Distance Education in Asia and the Pacific" (Revised Edition 1994). From this latest survey, the following information regarding library and information science via

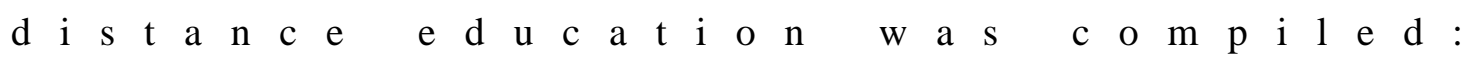

1. Library and information science via distance education is provided in seven countries in Asia and the Pacific, region namely: Australia, Republic of China, Republic of India, Japan, New Zealand, Papua New Guinea and Thailand.

2. Various levels are offered: including diploma, graduate diploma, post graduate diploma, associate and bachelor degrees.

Besides, in 1998, the author makes a small survey by accessing the International Centre for Distance Learning (ICDL) database, reviewing related literature in the field and 
sending questionnaires to the leading information educators in some countries in which information is not provided. Information was analyzed and it was founded as follows:

1. Distance education in library and information science is provided by thirty one institutions in nine countries in Asia and the Pacific region. (See Appendix)

2. Various levels of courses are offered leading to certificate, diploma, bachelor's, master's and doctorate degree programs. Many short courses are also provided.

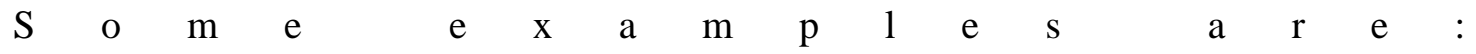

- Australia: Charles Sturt University awards Diploma in Library and Information Science, Bachelor of Arts (Library and Information Science), Master of Applied Science (Library and Information Management), Graduate Diploma of Applied Science (Library and Information Management), Ph.D.(Information Science). Victorian TAFE Off-Campus Network, Department of Technical and Further Education awards Associate Diploma of Applied Science (Library and Information Studies).

- Fiji: University of the South Pacific awards Diploma in Library/

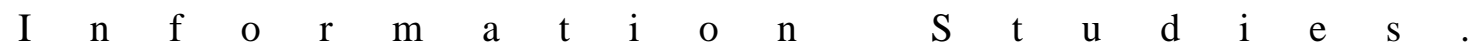

- India: Indira Gandhi National Open University awards Master in Library and Information Science; Kakatiya University awards Bachelor of Library and Information Science and Certificate in Library and Information Science.

- New Zealand: Victoria University of Wellington awards Master of

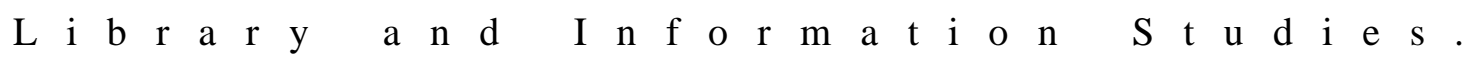
- Pakistan: Allama Iqbal Open University awards Bachelor of Arts

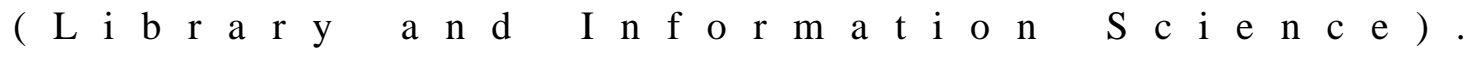
- Thailand: Ramkamhaeng University awards Bachelor of Arts (Library and Information Science) and Master of Arts (Library and Information Science). Sukhothai Thammathirat Open University awards Diploma in Information Science and Bachelor of Arts (Information Science). Various individual courses in the information science program are also offered to the general public through the continuing education project leading to the Certificate of Achievement. 


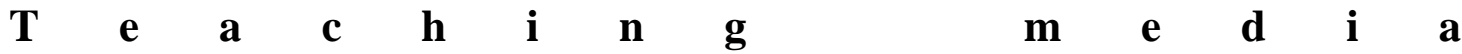

The most dominant teaching media for distance education in library and information science used by institutions in Asia and the Pacific region is print media, which comprises of study materials and textbooks. Radio and television broadcast, face-to-face tutoring, practical work, home lab kits and residential schooling are dominant. Others are audiocassettes, video-cassettes, computer-assisted instruction, telephone tutoring, tutorial via mailing, counseling via mailing, counseling by telephone, counseling via other media. tutorial via audio-teleconferencing, compact-disc, tutorial via video teleconferencing. There is growing use of interactive telecommunication media especially video conferencing and computer communication. The Internet is being introduced more widely $\begin{array}{lllllllllll}\text { a } & \mathrm{n} & \mathrm{d} & \mathrm{r} & \mathrm{a} & \mathrm{p} & \mathrm{i} & \mathrm{d} & 1 & \mathrm{y}\end{array}$ The teaching media are usually produced by full-time and part-time academics on the course team basis for material development. Radio and television broadcast, audiocassettes and video-cassettes are produced by academic staff working with the Educational

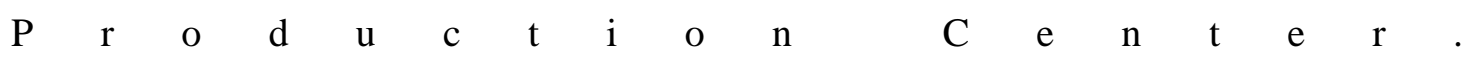
$\begin{array}{llllllllllllllllllll}\mathbf{I} & \mathbf{n} & \mathbf{S} & \mathbf{t} & \mathbf{r} & \mathbf{u} & \mathbf{c} & \mathbf{t} & \mathbf{i} & \mathbf{0} & \mathbf{n} & \mathbf{a} & \mathbf{l} & & \mathbf{s} & \mathbf{y} & \mathbf{s} & \mathbf{t} & \mathbf{e} & \mathbf{m}\end{array}$ The instructional system is mostly print-based. Students study from printed materials mailed to them, listen to radio programs and audio tapes, watch television programs and video programs and engage in interactive communication such as teleconferencing. In some subjects, they have to carry out practical/ laboratory work, attend a series of required face-to-face tutorial sessions, and counseling of varying duration, according to the

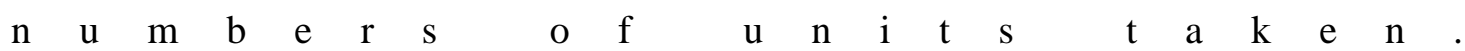

Evaluation is made in different forms: continuous assessment, written assignments for submission, practical work, attendance of regular workshops, and written final examinations which are conducted at various study centers around the country. 


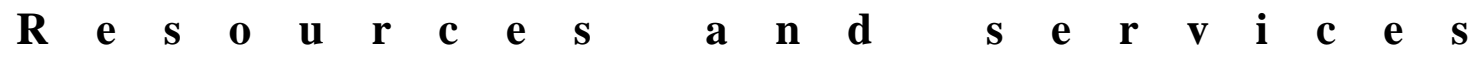

The most dominant resources are library resources, local study centers, regional centers and resource centers, special study centers and cooperating government and private institutions. This provides numerous contact points for students and allows full use of learning resources to enrich distance education.

Student support services are helpful in solving the academic and non-academic problems of distance education students. Services to distance learners generally include tutorials, library services, computer services, educational and vocational counseling services, and $\begin{array}{llllllllllllllllllllllllllllll}\mathrm{p} & \mathrm{o} & \mathrm{f} & \mathrm{e} & \mathrm{s} & \mathrm{s} & \mathrm{i} & \mathrm{o} & \mathrm{n} & \mathrm{a} & \mathrm{l} & \mathrm{p} & \mathrm{r} & \mathrm{a} & \mathrm{c} & \mathrm{t} & \mathrm{i} & \mathrm{c} & \mathrm{a} & \mathrm{l} & \mathrm{e} & \mathrm{x} & \mathrm{p} & \mathrm{e} & \mathrm{r} & \mathrm{i} & \mathrm{e} & \mathrm{n} & \mathrm{c} & \mathrm{e}\end{array}$

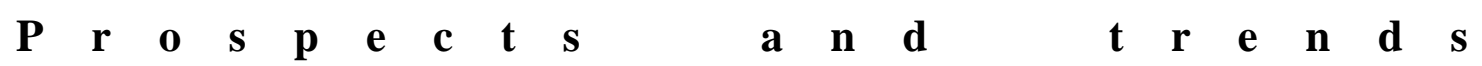
Distance education came to the attention of the experts from 11 countries in the consultative meeting and workshop on "Planning Human Resource Development for Information Societies" at Sukhothai Thammathirat Open University (STOU) Thailand between 3-7 March 1997. This meeting and workshop was convened as a planning exercise to develop strategies for improving the education and training of information professionals in the Asia/Pacific region. This meeting was jointly organized by Sukhothai Thammathirat Open University and UNESCO Bangkok, Thailand, and supported by the Ministry of Education, Science, Sports \& Culture, Government of Japan.

At the Meeting, the members agreed on a regional program with one of its specific

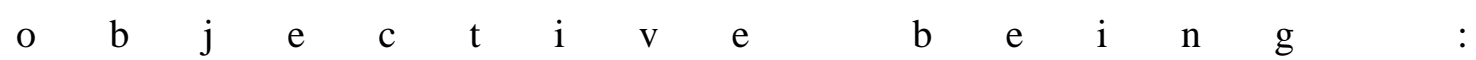
To enhance the provision of distance learning for information professionals and workers taking into consideration the special needs of rural libraries by: a) expanding the STOU survey and publishing the results on the World Wide Web, b) providing training in the development of distance learning programs, c) developing distance learning packages on specific topics to meet high priority training needs (STOU and UNESCO 1997: 15).

To implement the distance program, at the Meeting, it was agreed that STOU be approached to help with the survey on institutions in the region which offer library and 
information science through distance education, providing training to the library and information schools in the Region on how to develop distance education programs; collecting, developing and disseminating information and packages on distance education programs for information professionals and workers (STOU and UNESCO 1997: 17).

Distance education in library and information science in Asia and the Pacific region grows larger. Its importance and standards are accepted. There is a good prospect and trend that there will be more countries and more institutions offering library and information science distance education, Various integrated multimedia will be used to provide academic instruction. However, printed materials will still be the basic instructional media in Asia and the Pacific region for the coming years. This is because of the economic situation being a major problem. Information and technological infrastructure are also basic $\mathrm{p}$ r o b 1 e m $\mathrm{S}$ S $\mathbf{u}$ m m a r $\mathbf{y}$

Distance education is now recognized throughout the world as a viable alternative to campus-based education and remains competent in today's digital era and knowledge society. Distance education in library and information science, which started in 1988, has grown rapidly to a wider audience in Asia and the Pacific region. The number of countries and institutions offering library and information science distance education has increased and various levels of degree programs and short courses are offered. It expands the reach of the classroom by using various technologies to deliver university resources and services to off-campus sites, and by transmitting courses into the workplace, thus enabling informational professionals to view class lectures in the comfort of their homes and offices. Library and information science distance education comes as an integral part for information professionals of not only "Education for All" but also "Education for $\mathrm{T}$ o $\mathrm{m}$ O $\mathrm{r}$ $r$ o W 


\section{Bibliography}

Barron, Daniel D. "Distance Education in North American Library and Information Science Education: Applications of Technology and Commitment." Journal of the American Society for Information Science 47 (November 1996): 8058

1 0

Barron, Daniel D. "The Library and Information Science Distance Education Consortium: The Profession's Virtual Classroom." Wilson Library Bulletin (October $\begin{array}{llllllllllll}1 & 9 & 9 & 1 & ) & : & 4 & 1 & - & 4 & 3\end{array}$

Garrison, D. Randy and Shale, Doug, eds. Education at a Distance:From Issues to Practice. Malabar, Florida: Robert E. Krieger Pub. Co., 1990. Haythornthwaite, J.A. and White, FCP. Distance Education in Library and Information Studies: a Survey. "British Library Research Paper 50." West Yorkshire: British Library Research and Development Department, 1989. "ICDL Institutions and Courses Database." 1998 (Online). Available http://www-

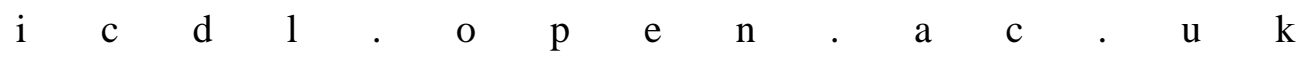
Markowitz, Harold. Distance Education: Staff Handbook. "The Guide Series." Urbana-Champaign : University of Illinois at Urbana-Champaign, 1990. National Institute of Multimedia Education. Distance Education in Asia and the Pacific. "Report on Multimedia Education 66E." Revised Edition. Chiba: NIME, 1994. The Open Learning Directory 1997. Oxford: Butterworth-Heinemann, 1997.

Perry, W. Open University. Milton Keynes: Open University Press, 1976.

Peters, O."The Tieberg has not Milked: Further Reflections on the Concept of Industrialization and Distance Teaching." Open Learning 6 (1989): 3-8. Peterson's Distance Learning 1997. Princeton, N.J.: Peterson's, c 1996. "Programmes at Open University included in the ICDL Database." 1998 (Online). Available: http://www-icdl.open.ac.uk/icdl/export/europe/unitedki/openuniv/

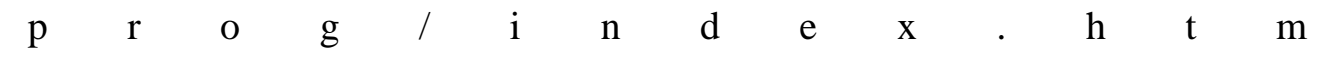

Stoker, David. "Editorial: Information and Library Studies at a Distance." Journal of Librarianship and Information Science 27 (March 1995): 3-5. 
STOU (Sukhothai Thammathirat Open University) and UNESCO Bangkok, Thailand. Report of the Consultative Meeting and Workshop: Planning Human Resources Development for Information Societies. Bangkok, 1997 (Supported by the Ministry of Education, Science, Sports \& Culture.

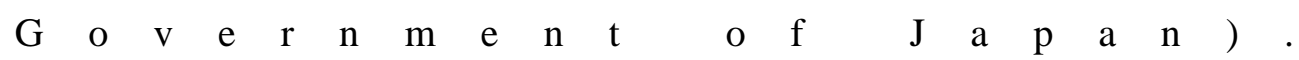




\section{Appendix}

Names of institutions in Asia and Pacific offering courses in library and information science via distance education

A

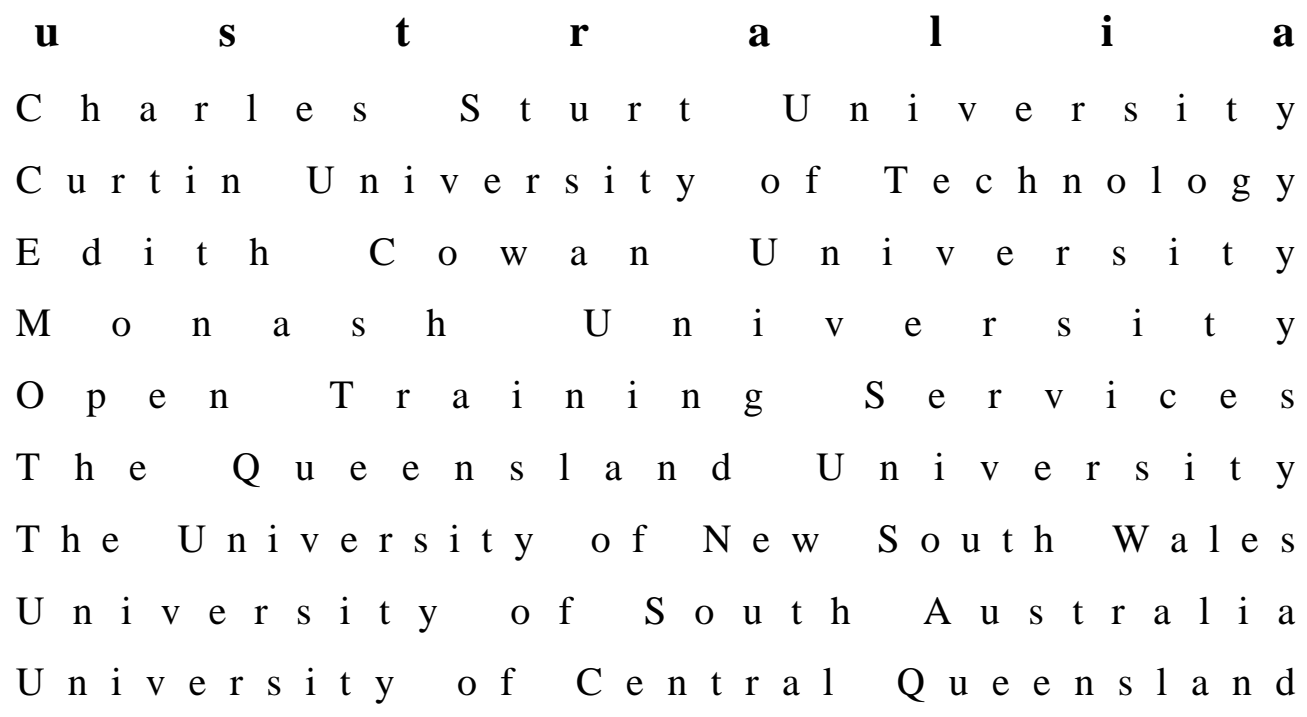

Victorian TAFE Off Campus Network. Department of Technical and Further

$\begin{array}{lllllllll}\text { E } & d & u & c & a & t & i & o & n\end{array}$

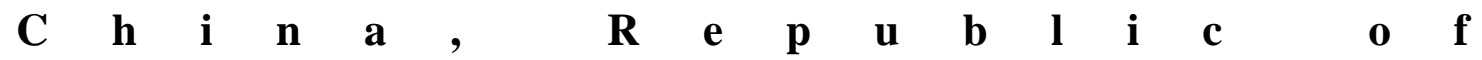

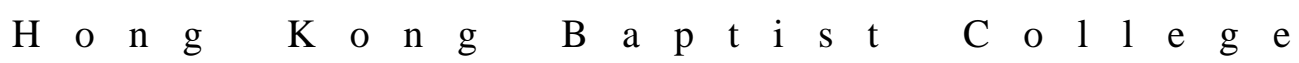
Central Radio and Television University

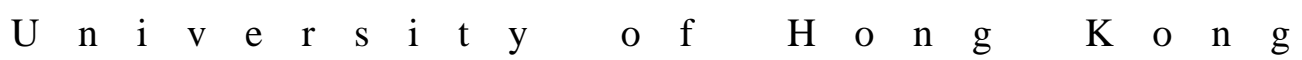
$\begin{array}{llll}\mathbf{F} & \mathbf{i} & \mathbf{j} & \mathbf{i}\end{array}$

University of $t h e \quad S$ o u t h P a c i f i c

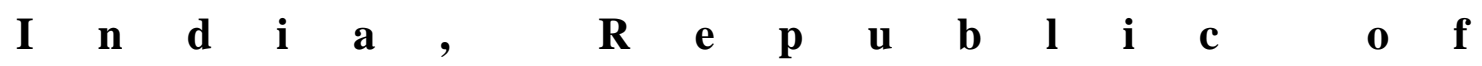
$\begin{array}{lllllllllllllllllll}\text { A } & n & n & a & m & a & 1 & \text { a } & \text { i } & \text { U } & n & \text { i } & \text { v } & \text { e } & \text { r } & \text { s } & \text { i } & \text { t } & \text { y }\end{array}$ B irla Institute of Technology and Science D r. B. R. A m b e d k a r O p e n U n i ve r s i t y Indira Gandhi National Open University

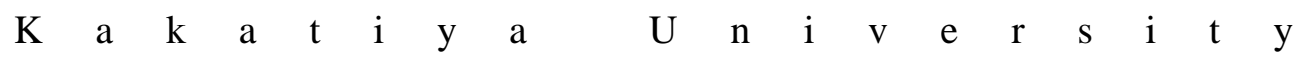

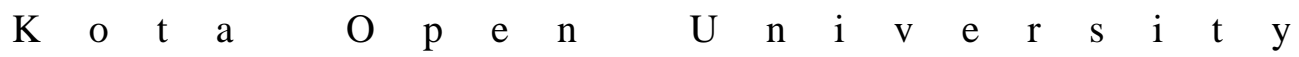

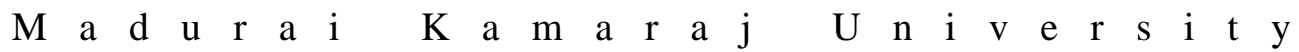

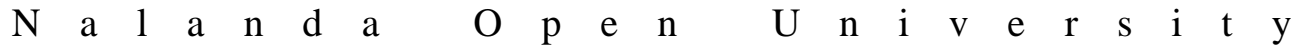




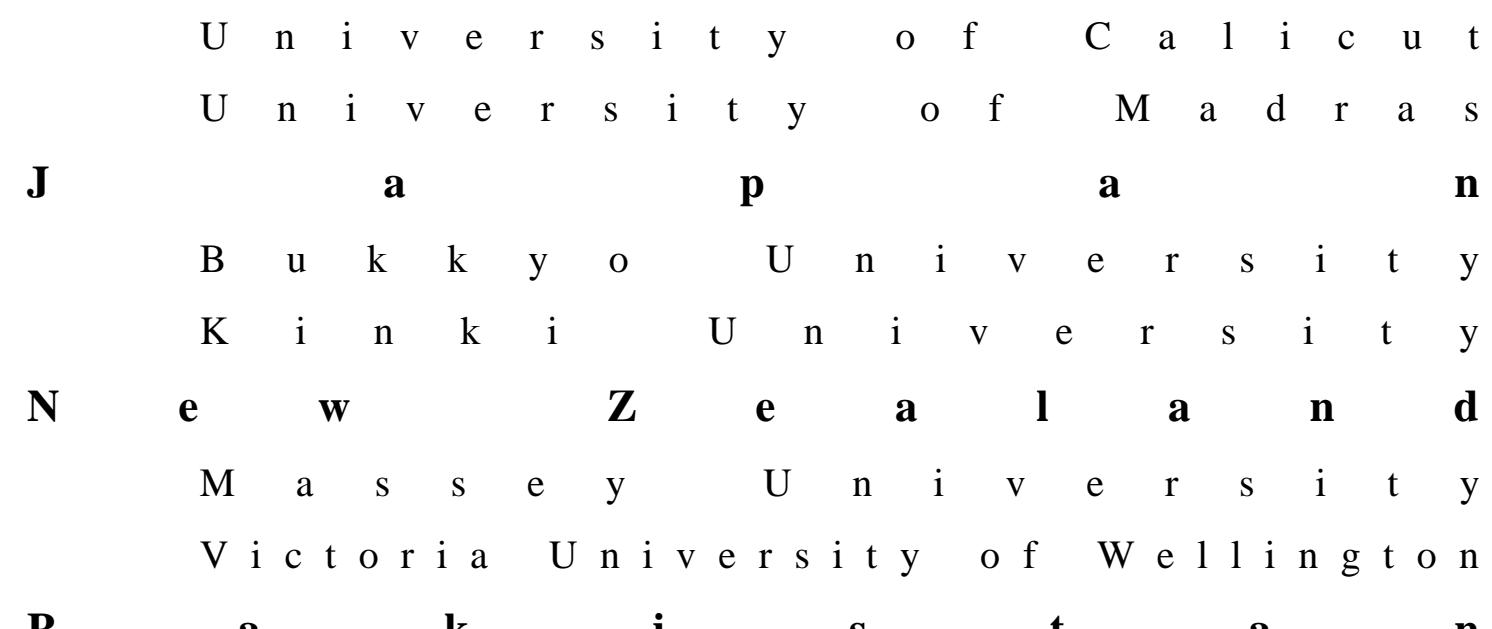

$\begin{array}{llllllll}\mathbf{P} & \mathbf{a} & \mathbf{k} & \mathbf{i} & \mathbf{s} & \mathbf{t} & \mathbf{a} & \mathbf{n}\end{array}$

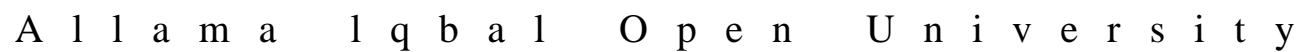
$\begin{array}{llllllllllllll}\mathbf{P} & \mathbf{a} & \mathbf{p} & \mathbf{u} & \mathbf{a} & \mathbf{N} & \mathbf{e} & \mathbf{w} & \mathbf{G} & \mathbf{u} & \mathbf{i} & \mathbf{n} & \mathbf{e} & \mathbf{a}\end{array}$ U n i v e r s i t y o f P a p u a N e w G u i n e a $\begin{array}{llllllll}\mathbf{T} & \mathbf{h} & \mathbf{a} & \mathbf{i} & \mathbf{l} & \mathbf{a} & \mathbf{n} & \mathbf{d}\end{array}$

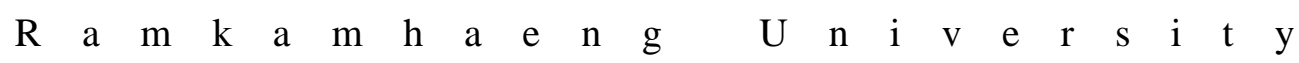
Sukhothai Thammathirat Open University 